\title{
SOCIO-HISTORICAL TRADITIONS OF DEVELOPMENT OF ECOESTHETIC CULTURE OF PRESCHOOL EDUCATIONAL PROFESSIONALS
}

\author{
Oygul Anvarjonovna Ashurova
}

Researcher Department of Preschool Education, Fergana State University

\section{ABSTRACT}

The article summarizes the socio-historical traditions of the development of eco-aesthetic culture of preschool education professionals and its modern determinants. It also analyzes information on the process of social education aimed at shaping the social qualities of future preschool professionals, creating and expanding the scope of their relationships with the environment, society, people and themselves.

KEYWORDS:- Ecoesthetic culture, ecological knowledge, ecological education, ethical requirements, aesthetics, social requirements, family

\section{INTRODUCTION}

The formation of eco-aesthetic culture today remains the focus of biologists, geographers, ecologists, philosophers, sociologists, physiologists and pedagogical scientists. Therefore, for the development of eco-aesthetic culture, the study of literature in the field of ecology, pedagogy, higher education, as a result of their analysis, the problem of formation of ecological culture in students plays an important scientific and pedagogical role.

In the formation of the eco-aesthetic culture of future personnel, in the process of studying ecological knowledge, it is the duty of citizens to study history, science, humanity, continuity, inheritance, nature conservation in the country and care for the environment. openness, validity of ecological education content, strong interaction and cooperation between family, community, educational institutions, nature protection bodies and the state on formation of ecological culture, establishment of international cooperation in protection of ecosystem of the republic, ecological education based on national and universal values scientific and pedagogical development of such principles is gaining momentum.

Having an eco-aesthetic culture, the formation of aesthetic values and norms in relation to nature should be directly related to practical activities. Therefore, the main task of the formation of ecological culture in higher education is to 
CURRENT RESEARCH JOURNAL OF PEDAGOGICS 2(5): 46-52, May 2021

DOI: https://doi.org/10.37547/pedagogics-crjp-02-05-10

ISSN 2767-3278

(C)2021 Master Journals

\section{Crossref do) 81 Google}

Accepted 23 ${ }^{\text {th }}$ May, 2021 \& Published 28 $8^{\text {th }}$ May, 2021

prepare students to participate in the protection and improvement of the natural environment, rational use of nature, spiritual and ecological education, conservation and reproduction of Mother Nature. In this regard, this chapter pays special attention to the tasks of the formation of ecological culture, the essence of such concepts as ecological consciousness, ecological activity, ecological activity, ecological knowledge, ecological thinking, environmental control and their integration.

As a result, it is based on the development of students' ability to express an aesthetic attitude to nature, to show personal example and initiative in the field of nature protection, to organize independent environmental activities. The formation of ecological culture tasks in students is reflected in their exemplary attitude to the environment, to the gifts of nature, to their homeland, to every inch of it. This chapter provides recommendations on the effective direction of these tasks in the implementation of environmental education.

Materials and methods

In all historical periods, people have had an attitude towards nature. The works of Eastern thinkers emphasize the qualities of honesty, cleanliness, cleanliness of the environment and love of nature. Our compatriot Ibn Sina put forward the theory that "human life is prolonged without dust in nature." The Czech pedagogue J.A. Comenius [1] in the XVII century tried to scientifically substantiate the essence of the educational process. The scientist substantiated the idea that the mental and physical development of a child is in accordance with the laws of nature.

In the 18th century, the French scientist JeanJacques Rousseau [2] also tried to explain the essence of education on the basis of philosophical ideas about the role of man in nature and society. According to him, the essence of the educational process is based on the child's knowledge of the environment.

Means of ecological and delicate education are the factors used in the pedagogical process aimed at the organization of life, nature, the beauty of art and children's artistic activity in order to educate students in the spirit of love of beauty. Nature, labor, human relations are a means of ecological education. Nature is an important source of environmental education. K.D. Ushinsky [3] said that nature is a wonderful educator that has a profound effect on the development of aesthetic feelings of the younger generation. Travel, travel, study of works of art dedicated to nature are traditional activities in this area. But being in nature is not enough. It is necessary to be able to see and feel the beauty of nature. This ability develops gradually. During field trips and field trips, teachers should explain to students that focusing on the riches of nature, the perfection of its form, is not only a need to love nature, but also to care for it.

Result and discussion

We now understand that the law is not the only social tool that regulates the eco-aesthetic culture of citizens, but at the same time it is an official spiritual force that promotes the ecological education of every citizen. Citizens are obliged to abide by the Constitution [4] and laws, as well as to treat the environment with care. In the process of forming ecological education in students, teaching the laws alone is not enough. At the same time, events dedicated to the research and promotion of ecological culture also contribute to the formation of ecological culture. In any social society, the upbringing of the younger generation is organized on the basis of a specific goal. The purpose of education is determined by the development of social society, its direction of development, the content of social relations. The main purpose of education in the Republic of Uzbekistan today is to bring up a 
CURRENT RESEARCH JOURNAL OF PEDAGOGICS 2(5): 46-52, May 2021

DOI: https://doi.org/10.37547/pedagogics-crjp-02-05-10

ISSN 2767-3278

(C)2021 Master Journals

\section{Crossref do) 81 Google}

Accepted 23th May, 2021 \& Published 28 ${ }^{\text {th }}$ May, 2021

mature person. The result of education is the training of highly qualified personnel who meet high moral and ethical requirements. This process is two-way and requires organizational and leadership, as well as active participation by the students themselves. The educator plays a leading role in this process. He understands the general purpose of social education, is aware of the system of tasks to achieve it, is able to correctly choose the form, methods and means of education and apply it to the educational process.

The essence of the educational process can be successfully scientifically analyzed with a comprehensive approach to education.

A person is a social being that is formed as a result of upbringing. The many qualities of a person are not separated from each other, but are strongly intertwined. In the process of upbringing, the child's personality develops as a whole, not individually. As the child grows and develops, the tasks of upbringing become more complex, deeper and stratified.

The upbringing of a comprehensively mature person is a consistent intellectual, ideological, political, moral, labor, aesthetic, physical, ecological, economic and legal education, the unity of consciousness, behavior and activities of students, as well as the organization of the educational process. the creation of pedagogical systems that ensure the integration of group and mass forms and the adherence to the ideas of this system.

The process of social education is aimed at shaping the social qualities of future preschool education professionals, creating and expanding the scope of their relationships with the environment, society, people and themselves. The broader, more diverse, and deeper the system of social relations in which students participate in higher education, the richer their spirituality. It is known that the attitude to the formation of ecological culture has a historical character. Created on the basis of the sacred religion of Zoroastrianism, one of the oldest historical monuments, the Avesto pays special attention to the relationship with nature. It calls people to honesty and justice; ideas of urban and rural beautification, expansion of pastures; it is important to have ideas that encourage people to improve their cultural lifestyles. These ideas are consistent with the leading ideas in our modern society. From year to year, our cities and villages are becoming more prosperous and beautiful. These results indicate that the ecological culture of our citizens has increased.

By its very nature, the process of upbringing is multifactorial in nature. That is, the establishment of ecological culture in students takes place under the influence of family, educational institution, community, social environment, as well as the diversity of situations, direct and indirect.

Eco-aesthetic education is another important component of social education. Mental, moral, labor, and aesthetic education cannot be imagined without an ecological culture. The formation of ecological culture in students has a great impact on the moral image, the formation of positive norms of behavior, the development of their creative abilities.

The teaching of sciences such as natural sciences, biology, geography and aesthetics in the system of continuing education is an effective means of eco-aesthetic education. Explaining to students the unity and connection of the individual, society and nature on the basis of ecological knowledge in ecological education, to determine their understanding of the important role and importance of the ECO-system in the development of man, humanity, society, to treat nature with care and responsibility. it is necessary to take care of the preservation of emotions, to form an ecological culture. 
CURRENT RESEARCH JOURNAL OF PEDAGOGICS 2(5): 46-52, May 2021

DOI: https://doi.org/10.37547/pedagogics-crjp-02-05-10

ISSN 2767-3278

(C)2021 Master Journals

\section{Crossref dof 81 Google}

Accepted 23 $3^{\text {th }}$ May, 2021 \& Published 28 $8^{\text {th }}$ May, 2021

The concept of "ecology" was first developed by the German scientist E. Used by Haeckel. Environmental education is an important component of social education.

Eco-aesthetic education is a pedagogical process aimed at shaping the initial ecological and aesthetic worldview of kindergarten students, imparting knowledge, enriching existing ecoaesthetic knowledge, the formation of skills and abilities to organize nature and environmental protection.

In the Republic of Uzbekistan, special attention is paid to the organization of nature and environmental protection. The idea of social and ecological movement is reflected in the "Program of actions for environmental protection in the Republic of Uzbekistan for 2013-2017", approved by the Cabinet of Ministers of the Republic of Uzbekistan on May 27, 2013 No 142 [5].

Among the goals and objectives of this program is to create conditions that will promote the dissemination of environmental knowledge, as well as the development of environmental culture.
Tasks "Action Plan for Environmental Protection in the Republic of Uzbekistan for 2013-2017" development of nature protection legislation and regulatory framework in the field of environmental protection and nature management, environmental education and education for sustainable development;

For the purposes of sustainable
development, it is planned to establish
training and methodological centers for
education and professional development of
employees of organizations that develop the
system of the State Committee for Nature
Protection and regulatory and technical
documents for environmental services.

Figure 1. "Program of actions for environmental protection in the Republic of Uzbekistan for 2013 2017"
The measures to be taken in the main areas of implementation of this program include:
- development of nature protection legislation and regulatory framework in the field of 
CURRENT RESEARCH JOURNAL OF PEDAGOGICS 2(5): 46-52, May 2021

DOI: https://doi.org/10.37547/pedagogics-crjp-02-05-10

ISSN 2767-3278

(C)2021 Master Journals

Crossref dof 81 Google

Accepted 23th May, 2021 \& Published 28 ${ }^{\text {th }}$ May, 2021

environmental protection and nature management, environmental education and education for sustainable development;

- Establishment of training and methodological centers for education and professional development of employees of the system of the State Committee for Nature Protection and the development of regulatory and technical documents for environmental services for sustainable development.

Deciding on the right attitude towards nature, awakening love, achieving environmental purity in future preschool professionals is an important step in solving aesthetic problems.

Eco-aesthetic education is an educational process aimed at imparting theoretical ecoaesthetic knowledge to preschoolers in a purposeful, consistent, systematic and continuous manner. Theoretical ecological knowledge (ecological consciousness), the unit of activity carried out in the way of environment and nature protection, serves to form ecological culture.

Ecoesthetic consciousness is the conscious expression of the existing state of nature and the environment, the concepts of their protection, which manifests itself as a complex sociopsychological phenomenon.

Eco-aesthetic culture is the ability of the student to organize the protection of nature and the environment in accordance with social requirements.

Eco-aesthetic activity is a process carried out to ensure the protection of nature and the environment based on environmental knowledge. Discussions on environmental issues, round tables, excursions, debates, creative contests, meetings, socially useful work (Saturday, hashar, landscaping) in higher education institutions, family and society increase the effectiveness of environmental education. Personal samples of subjects involved in the educational process, educational sources, fiction, ideas of mass media (including the Internet) are important tools for the formation of environmental culture in students. 


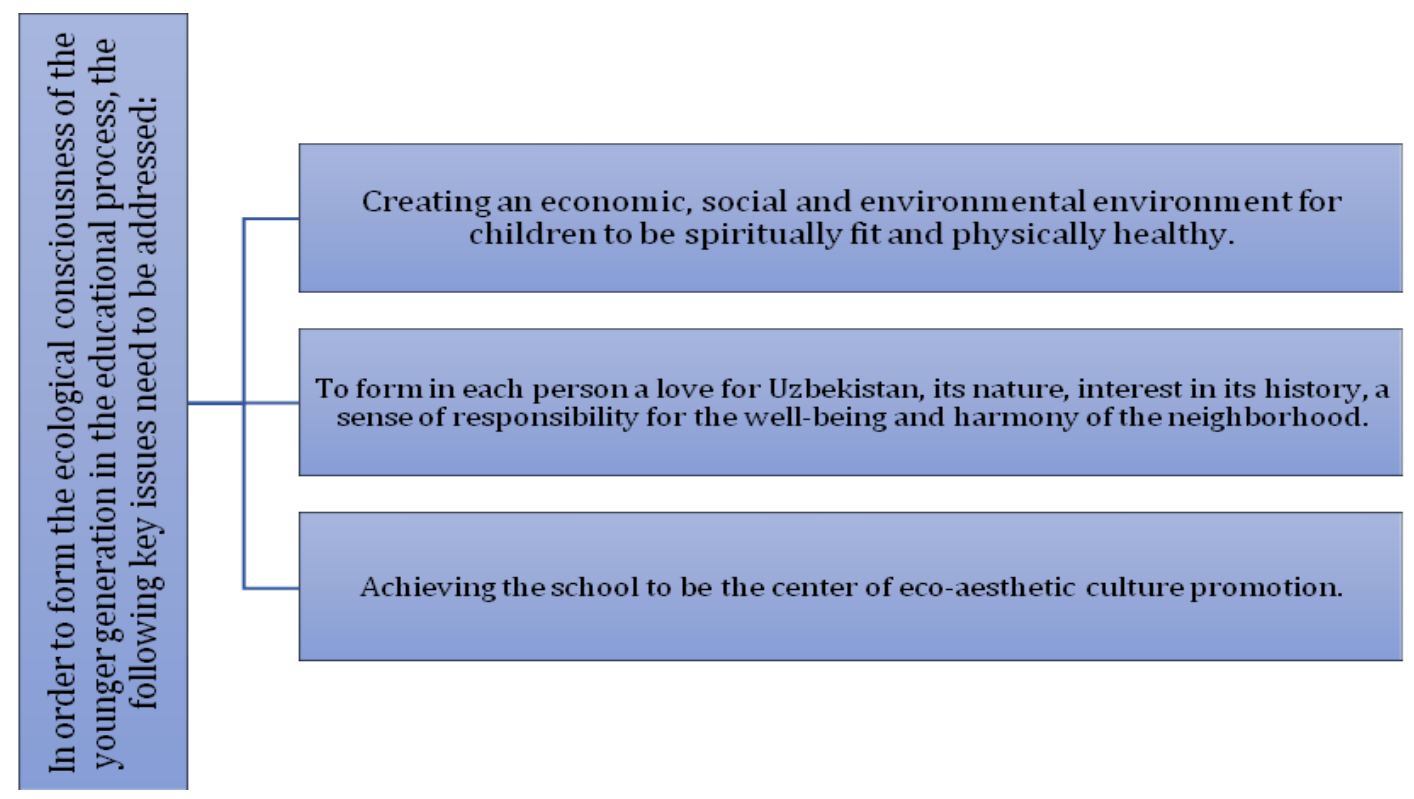

Figure 2. Issues of formation of ecological consciousness of the younger generation in the educational process

Socially useful work prepares the younger generation to take an active part in the organization of public life. The role of the family in the formation of eco-aesthetic culture in students is important. The material well-being and well-being of the family, the level of cultural life, the stability of a healthy environment, the psychological attitude of family members, the existence of mutual cooperation contribute to the socialization of the individual in society. Family work teaches children to be prudent, to work in a planned way, to use time efficiently, to save money, as well as to preserve the benefits of the labor of others, the product of human labor.

The family also organizes educational work on environmental protection (ecology), in the process of which the groundwork is laid for the development of ideas about the interaction between the concepts of "human-nature-society" in children. Sweeping the yard, arranging flower beds, planting and caring for seedlings, and taking care of household waste create a sense of responsibility for nature conservation in children.

Recognizing that the experience of Uzbekistan in the field of education of the younger generation is worth emulating in all respects, we are once again convinced of the correctness of the specific path of development of our country, in particular, the ongoing reforms in education.

When talking about the education system, first of all, it is necessary to dwell on the concept of education. Education is the study of the elements of nature and society on the basis of strict norms established by the state, and is a goal-oriented process in the interests of the individual, society and the state. Creating an effective, consistent system of environmental education in the system of continuing education, a positive solution to the problems of forming an ecological culture is important in the social life of society. 
CURRENT RESEARCH JOURNAL OF PEDAGOGICS 2(5): 46-52, May 2021

DOI: https://doi.org/10.37547/pedagogics-crjp-02-05-10

ISSN 2767-3278

(C)2021 Master Journals

Crossief do) 88 Google

Accepted 23th May, 2021 \& Published 28 ${ }^{\text {th }}$ May, 2021

\section{Conclusion}

In short, if pedagogical education did not cover all spheres and aspects of the process of social life, it would not have taken the position of the main social science, which has great potential in the education of the perfect man. It should become a human quality of every person to have ecological knowledge, to have ecological culture, enlightenment and culture, to be accustomed to consider the laws sacred and to act without doubting them.

\section{REFERENCES}

1. Коменский Я. А. Великая дидактика. ООО ДиректМедиа, 2013.

2. Длугач, Т. Б. (2012). Жан-Жак Руссо: философ и писатель. Ценности и смыслы, (4 (20)).

3. Ушинский К. Д. Человък как предмет воспитания: опыт педагогической антропологи. - Tip. AM Kotomina, 1873. T. 1.

4. Ўзбекистон Республикасининг Конституцияси. - Т.: «Ўзбекистон», 2020.

5. https://lex.uz/docs/2174869

6. Bakhromovich, S. I. (2018). Social and philisophical performance of making youth's intellectual culture. European science review, (7-8). 